\title{
Suvremene promjene sastava stanovništva Srednje Like prema dobi i sektoru dielatnosti — primjena prostorne i demogeografske analize
}

\author{
Marta HAMZIĆ \\ Ericsson Nikola Tesla d.d., Zagreb \\ Izvorni znanstveni rad \\ Primlieno: 5. svibnja 2021. \\ UDK: $314.116(497.562-191.2)^{\prime \prime 1971+2011 " ~}$ \\ doi: $10.5559 /$ pi. 16.31 .02
}

Glavni je cilj rada utvrđivanje suvremenih promjena sastava stanovništva Srednje Like prema dobi i prema sektoru djelatnosti. U tu svrhu provedene su prostorna i demogeografska analiza korištenjem popisnih podataka za godine 1971. i 2011. na prostornoj razini jedinice lokalne samouprave (kao i njihovih sjedišta) te za Srednju Liku u cjelini, a opažanja na terenu pridonijela su razumijevanju utjecaja utvrđenih procesa na prostor, odnosno krajolik Srednje Like. Također, kako bi se dobio bolji uvid, provedena je analiza kretanja ukupnog broja stanovnika Srednje Like u razdoblju od druge polovine 20. stoljeća. Promatrajući dob stanovništva, rezultati istraživanja su pokazali kako je u promatranom razdoblju na svim promatranim razinama došlo do značajnog starenja stanovništva čime dobno-spolna piramida poprima oblik urne. Pri tome je za obje promatrane godine najveća ostarjelost stanovništva zabilježena u Općini Lovinac, a najmanja u Gradu Gospicu. Nadalje, u promatranom je razdoblju zbog starenja stanovništva na području Srednje Like opća stopa aktivnosti sve niža. Također, došlo je do prestrukturiranja stanovništva prema djelatnostima tercijarnog i kvartarnog sektora uz napuštanje tradicionalnih primarnih djelatnosti. S obzirom na trenutačne okolnosti, u narednim popisima stanovništva očekuje se na analiziranom području daljnji nastavak izrazito nepovoljnih demografskih i ekonomskih procesa.

Ključne riječi: sastav stanovništva prema dobi, sastav stanovništva prema sektoru djelatnosti, prostorna analiza, demogeografska analiza, krajolik, Srednja Lika

\section{Uvod}

Na području Republike Hrvatske postoje brojna gorska ruralna područja s izrazito nepovoljnim demografskim obilježjima kroz duže razdoblje. ${ }^{1} \mathrm{U}$ novije

${ }^{1}$ Na primjer, Maja ŠTAMBUK, "Lika — studija slučaja“, u: Duge sjene periferije: prinos revitalizaciji hrvatskog ruba (ur. I. Rogić, M. Štambuk), Institut društvenih znanosti Ivo Pilar, Zagreb (1998), 44-107; Ivo TURK, "Promjena broja stanovnika Karlovačke župa- 
su vrijeme u tim područjima izravnim i neizravnim posljedicama Domovinskog rata već prisutni nepovoljni demografski (i ekonomski) procesi dodatno intenzivirani. ${ }^{2}$

Srednja Lika je jedan od primjera takvih gorskih ruralnih područja gdje se nepovoljna demografska obilježja i procesi ogledaju i u sastavu stanovništva prema dobi i sektoru djelatnosti, te posljedično i u utjecaju na krajolik. Tako se za područje Srednje Like može reći kako je to tradicionalni stočarsko-poljoprivredni prostor, u kojem su takve prilike trajale sve do druge polovine 20. stoljeća kada je stvorena osnovna infrastruktura i provedena inicijalna industrijalizacija regije ${ }^{3}$ i započeo složeniji gospodarski razvoj. To je izravno utjecalo na ukupan broj stanovnika te sastav stanovništva prema dobi i djelatnosti, a posljedično i na krajolik, jer su se usporedno pojavili procesi deagrarizacije, a zatim i deruralizacije. Kako se tada stanovništvu nije moglo osigurati zapošljavanje, nastavljena su iseljavanja stanovništva s područja Srednje Like, nužno praćena i promjenama dobno-spolnog i gospodarskog sastava stanovništva.

Glavni je cilj ovoga rada utvrđivanje suvremenih promjena sastava stanovništva Srednje Like prema dobi i prema sektoru djelatnosti (za razdoblje

nije od 1857. do 2001. godine“, Društvena istraživanja 17 (2007) 3, 437-461; ISTI, Žumberak: demografska problematika i mogućnosti revitalizacije, Zagreb, Institut društvenih znanosti Ivo Pilar, 2021; Anđelko AKRAP i Jakov GELO, "Depopulacija Ličko-senjske županije tijekom 20. stoljeća s posebnim osvrtom na ekonomsko-socijalnu strukturu 1971._2001.", u: Identitet Like: korijeni i razvitak (ur. Ž. Holjevac), knjiga II., Institut društvenih znanosti Ivo Pilar — Područni centar Gospić, Zagreb — Gospić (2009), 13-41.

2 Na primjer, Jakov GELO, "Ratni učinci na promjene demografskih struktura u Hrvatskoj«, Društvena istraživanja 8 (1999) 5-6, 735-749; Dražen ŽIVIĆ, "Demografski gubici Ličko-senjske županije u Domovinskom ratu", u: Identitet Like: korijeni i razvitak (ur. Ž. Holjevac), knjiga II., Institut društvenih znanosti Ivo Pilar — Područni centar Gospić, Zagreb - Gospić (2009), 43-66; ISTI, "Prisilne (ratne) migracije kao čimbenik demografskih promjena u Hrvatskoj (1991.—2011.)،, u: Znanstveni skup Demografija u Hrvatskoj (ur. A. Akrap, I. Čipin i M. Strmota), Ekonomski fakultet, Zagreb (2014), 297-319; Ivo TURK, "Suvremene demografske promjene na kontaktnom prostoru Karlovačke i Ličko-senjske županije: analiza slučajau, u: Identitet Like: korijeni i razvitak (ur. Ž. Holjevac), knjiga II., Institut društvenih znanosti Ivo Pilar — Područni centar Gospić, Zagreb - Gospić (2009) 67-87; Nenad POKOS, "Demografske promjene na bivšim okupiranim područjima Republike Hrvatske između 1991. i 2001. godine“, u: Demografski kontekst i sociokulturne posljedice Hrvatskoga domovinskog rata (ur. D. Živić i I. Žebec), Institut društvenih znanosti Ivo Pilar - Područni centar Vukovar, Zagreb - Vukovar (2009), 11-27; Ivo TURK, Nikola ŠIMUNIĆ i Marta JOVANIĆ, "Promjene u sastavu stanovništva prema narodnosti u Karlovačkoj i Ličko-senjskoj županiji od 1991. do 2011.", Migracijske i etničke teme 31 (2015) 2, 275-309.

3 Dane PEJNOVIĆ, Srednja Lika: socijalnogeografska transformacija, Centar za kulturu - Muzej Like, Gospić, 1985. 
1971.-2011.). U tu svrhu primijenjena je prostorna, odnosno demogeografska analiza. Naime, uz popisno kretanje broja stanovnika od druge polovine 20. stoljeća, čime se dobiva temeljni uvid u promjene naseljenosti, analiziraju se i promjene u sastavu stanovništva prema dobi i sektoru djelatnosti s obzirom na prostornu komponentu. Time su usporedbom podataka popisa stanovništva iz 1971. i 2011. analizirane promjene dinamičkih obilježja sastava stanovništva prema dobi i djelatnosti, te su se utvrdili procesi do kojih je došlo u promatranom razdoblju. Opažanja na terenu pridonijela su razumijevanju utjecaja utvrđenih procesa na prostor, odnosno krajolik te su u radu promatrani i u funkciji utjecaja na krajolik Srednje Like.

\subsection{Područje istraživanja}

Područje Srednje Like odnosi se na središnji dio veće cjeline Like, ukupne površine približno $1690 \mathrm{~km}^{2}$. Administrativno, Srednja Lika obuhvaća područje triju jedinica lokalne samouprave: Grada Gospića, Općine Perušić i Općine Lovinac (sl. 1). Prema posljednjem popisu stanovništva (2011.) na području istraživanja zabilježeno je ukupno 16.390 stanovnika. Od toga je najviše stanovnika bilo na području Grada Gospića (12.745), a manje na području Općine Perušić (2638) i Općine Lovinac (1007).

Na području istraživanja ukupno je 78 naselja. Od toga je samo jedno naselje gradskog tipa, koje je ujedno i najveće - grad Gospić (6575 stanovnika, 2011.).

Upravno-teritorijalna podjela, na temelju koje su današnji Grad Gospić i Općina Perušić izdvojeni iz nekadašnje Općine Gospić, ustrojena je 1993. Iste je godine izdvajanjem iz nekadašnje Općine Gračac ustrojena i Općina Lovinac. Općina Lovinac pripojena je Ličko-senjskoj županiji 1997., a uslijed te upravno-teritorijalne organizacije stanovništvo Općine Lovinac gravitira prema Gradu Gospiću. S obzirom na tu činjenicu, u ovom radu prostor Srednje Like ima veći prostorni obuhvat i podrazumijeva navedene tri jedinice lokalne samouprave nego prema autorima D. Pejnoviću ${ }^{4}$ i D. Magašu5 koji ju smatraju dijelom Južne Like. Također je potrebno napomenuti kako je ovakav prostorni obuhvat područja Srednje Like usklađen s prostornim obuhvatom u pojedinim prostorno-razvojnim dokumentima. ${ }^{6}$

\footnotetext{
${ }^{4}$ D. PEJNOVIĆ, Srednja Lika: Socijalnogeografska transformacija.

5 Damir MAGAŠ, Geografija Hrvatske, Manualia Universitatis Studiorum Iadertinae, Sveučilište u Zadru, Odjel za geografiju, Biblioteka Geographica Croatica, Meridijani Samobor, Zadar — Samobor, 2013.

${ }^{6}$ Na primjer, Regionalni operativni program Ličko-senjske županije 2005.—2010., WYG International, Gospić, 2005.
} 


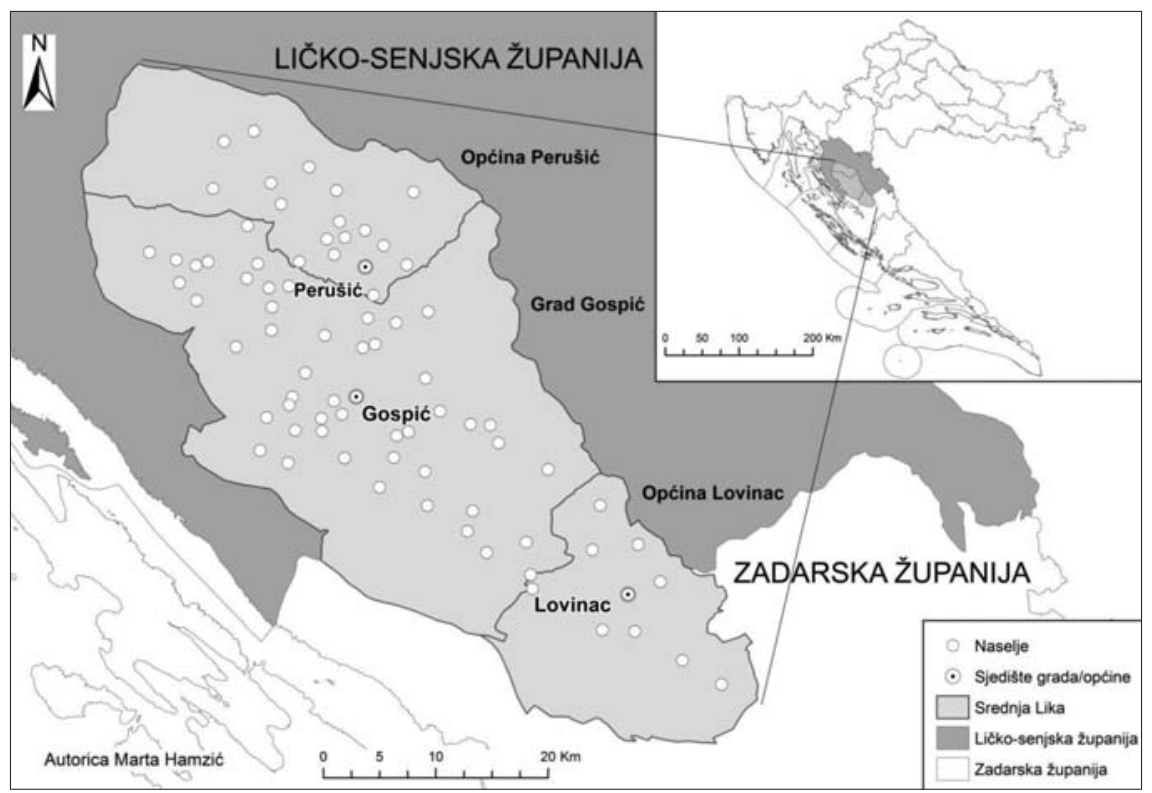

SI. 1. Srednja Lika - područje istraživanja

\subsection{Dosadašnja istraživanja}

Dosadašnja istraživanja o području Srednje Like bila su usmjerena na teme socijalne geografije i demogeografije, ali i na teme fizičke geografije, pri čemu su primijenjene različite metode istraživanja. D. Pejnović ${ }^{7}$ analizirao je međuzavisnosti obilježja prirodne osnove i historijsko-geografskih ciklusa naseljenosti Srednje Like (što čini osnovu za razumijevanje socijalno-geografskih procesa). M. Jovanić8 korištenjem različitih metoda (deskriptivno-analitičke, korelacijske analize i dr.) analizirala je razvoj krajolika Srednje Like do kojeg je došlo utjecajem demografsko-gospodarskih procesa.

Primjena GIS tehnologije bila je u dosadašnjim radovima koji se odnose na prostor Srednje Like usmjerena na različite teme. Tako je u radu M. Pahernika i M. Jovanić 9 uspostavljena geomorfološka baza podataka Srednje Li-

7 D. PEJNOVIĆ, Srednja Lika: socijalnogeografska transformacija.

${ }^{8}$ Autorica Marta Jovanić i autorica ovog rada Marta Hamzić su ista osoba. Marta JOVANIĆ, "Development of the Central Lika landscape (Republic of Croatia) caused by socio-economical processes" , u: International Scientific Symposium: Hilly-mountain areas - problems and perspectives (ur. B. Markoski i dr.), Makedonsko geografsko društvo, Skopje (2014), 23-30; Marta JOVANIĆ, "Correlation analysis demographic-economic variables and land use/land cover variables of central Lika", Acta geographica Bosniae et Herzegovinae 2 (2015) 3, 43-52; Marta JOVANIĆ, "GIS analiza i razvojna tipologija krajolika Srednje Like“, Doktorska disertacija, Sveučilište u Zagrebu, Prirodoslovnomatematički fakultet, Geografski odsjek, Zagreb, 2017. 
ke koja se, zbog jasno definiranih objekata unutar uspostavljene baze podataka, može povezati s ostalim geoznanstvenim bazama podataka koje će sadržavati ostale geografske sastavnice za područje Srednje Like. M. Hamzić, B. Fuerst-Bjeliš i M. Pahernik ${ }^{10}$ utvrdili su kombinacijom većeg broja analiza strukturna obilježja uzoraka krajolika Srednje Like, a M. Hamzić i B. Fuerst-Bjelišn ${ }^{11}$ primjenom prostorno i procesno-orijentiranog GIS modela definirale su tipove krajolika Srednje Like za razdoblje 1980.—2012.

Od navedenih se radova ovo istraživanje izdvaja jer uz primjenu prostorne i demogeografske analize promjene sastava stanovništva prema dobi i sektoru djelatnosti, kao i kretanja ukupnog broja stanovnika, opažanjima na terenu se dodatno te promjene promatraju i u funkciji utjecaja na krajolik.

\section{Metodološke napomene uz popisne podatke}

U svrhu glavnog cilja ovog rada, utvrđivanja suvremenih obilježja sastava stanovništva prema dobi i sektoru djelatnosti primjenom prostorne i demogeografske analize, u radu su analizirani odgovarajući popisni podaci. Tako su analizirani podatci popisa stanovništva iz 1971. i 2011. koji se odnose na dob, odnosno spol, te podatci koji se odnose na gospodarsku aktivnost, odnosno sektore djelatnosti.

U svrhu temeljne analize demografske dinamike i u cilju postizanja sveobuhvatnijeg pogleda na brojčanu dinamiku Srednje Like korišteni su objavljeni podatci svih popisa stanovništva u razdoblju od druge polovine 20. stoljeća do danas (1948. - 2011.). Naime, kako je u uvodnom dijelu rada navedeno, u tom razdoblju stvorena je temeljna struktura i implementirana inicijalna industrijalizacija regije, što je izravno utjecalo na ukupan broj stanovnika te sastav stanovništva prema dobi i djelatnosti, a posljedično i na krajolik. Potrebno je naglasiti kako je u tom razdoblju provedeno ukupno osam popisa, u kojima su zbog različitih popisnih koncepcija prisutne određene metodološke razlike. Popisi iz 1948., 1953., 1961., 1971., 1981. i 1991. provedeni su prema koncepciji stalnog stanovništva (tzv. de iure stanovniš-

\footnotetext{
9 Mladen PAHERNIK i Marta JOVANIĆ, "Geomorphologic database in the function of the Central Lika landscape typology (Republic of Croatia) «, u: International Scientific Symposium: Hilly-mountain areas - problems and perspectives (ur. B. Markoski i dr.), Makedonsko geografsko društvo, Skopje (2014) 97-105.

10 Marta HAMZIĆ, Borna FUERST-BJELIŠ i Mladen PAHERNIK, "Strukturna obilježja uzoraka krajolika Srednje Like - primjena prostorne i regresijske analize“, Kartografija i geoinformacije, 34 (2020) 19, 14-39, doi: 10.32909/kg.19.34.2

${ }^{11}$ Marta HAMZIĆ i Borna FUERST-BJELIŠ, "Razvojni tipovi krajolika Srednje Like 1980— 2012 - primjena prostorno i procesno-orijentiranog GIS modela", Kartografija i geoinformacije, 35 (2021) 20, 4-29, doi: 10.32909/kg.20.35.1
} 
tvo), ${ }^{12}$ a posljednja dva popisa, iz 2001. i 2011., provedena su prema prilagođenoj koncepciji uobičajenog mjesta stanovanja (engl. place of usual residence). ${ }^{13}$ Zbog metodoloških razlika između popisa stanovništva, popisni rezultati nisu u potpunosti usporedivi, ${ }^{14}$ ali pouzdaniji (potpuno usklađeni) demografski i ekonomski pokazatelji ne postoje. Time su službeni popisni podatci korišteni kao činjenični te su međusobno uspoređivani u namjeri što vjernijeg prikaza općih trendova kretanja promatranih pokazatelja Srednje Like.

\section{Promiene ukupnog broja stanovnika}

U razdoblju od druge polovine 20. stoljeća (1948.—2011.). na području Srednje Like svakim popisom zabilježeno je smanjenje ukupnog broja stanovnika (sl. 2). Tako se u ovom razdoblju od 63 godine ukupan broj stanovnika smanjio približno tri puta (sa 45.344 na 16.390), odnosno za 28.954 stanovnika ili prosječno godišnje za čak 460 stanovnika. Također je smanjenje ukupnog broja stanovnika zabilježeno u sve tri jedinice lokalne samouprave Srednje Like. Pri tome je najznačajnije smanjenje zabilježeno u Općini Lovinac (za 85,1\%), potom u Općini Perušić (za 77,4\%) i u Gradu Gospiću (za 52,7\%).

Neki od najznačajnijih razloga smanjenja ukupnog broja stanovnika pri tome su: iseljavanja stanovništva u veće gradove te u inozemstvo kao i demografski gubitci i posljedice Drugoga svjetskog rata i Domovinskoga rata. Također, od sredine 70-ih godina pridružena je i negativna stopa prirodne promjene, koja je uz navedene dodatan razlog kontinuiranog pada ukupnog broja stanovnika. ${ }^{15}$ Međutim, potrebno je naglasiti kako je to smanjenje ukupnog broja stanovnika u promatranom razdoblju (1948._2011.) jačeg intenziteta u rubnim područjima, a slabijeg intenziteta bliže gradu Gospiću, odnosno sjedištima jedinica lokalnih samouprava (Perušić, Lovinac). Stoga se može zaključiti kako je u tom razdoblju na području Srednje Like prisutan proces deruralizacije.

\footnotetext{
12 Više o koncepciji stalnog stanovništva u: Ivo NEJAŠMIĆ, Depopulacija u Hrvatskoj — korijeni, stanje, izgledi, Globus, Institut za migracije i narodnosti Sveučilišta u Zagrebu, Zagreb, 1991; Ivan LAJIĆ i Ivo NEJAŠMIĆ, "Metodološke osobitosti demografskog istraživanja hrvatskog otočja “, Društvena istraživanja, 4-5 (1994), 381-396.

13 Ivan LAJIĆ i Roko MIŠETIĆ, Otočni algoritam, aktualno stanje i suvremeni demografski procesi na jadranskim otocima, Institut za migracije i narodnosti, Ministarstvo mora, turizma, prometa i razvoja, Zagreb, 2006.

${ }^{14}$ Na primjer, Nenad POKOS, "Metodološke promjene u popisima stanovništva", Hrvatska revija, 3 (2003) 1, 29-35; Ivan LAJIĆ i Roko MIŠETIĆ, "Demografske promjene na hrvatskim otocima na početku 21. stoljeća“, Migracijske i etničke teme, 29 (2013) 2, 169-199 .

15 D. PEJNOVIĆ, Srednja Lika: socijalnogeografska transformacija, 68.
} 


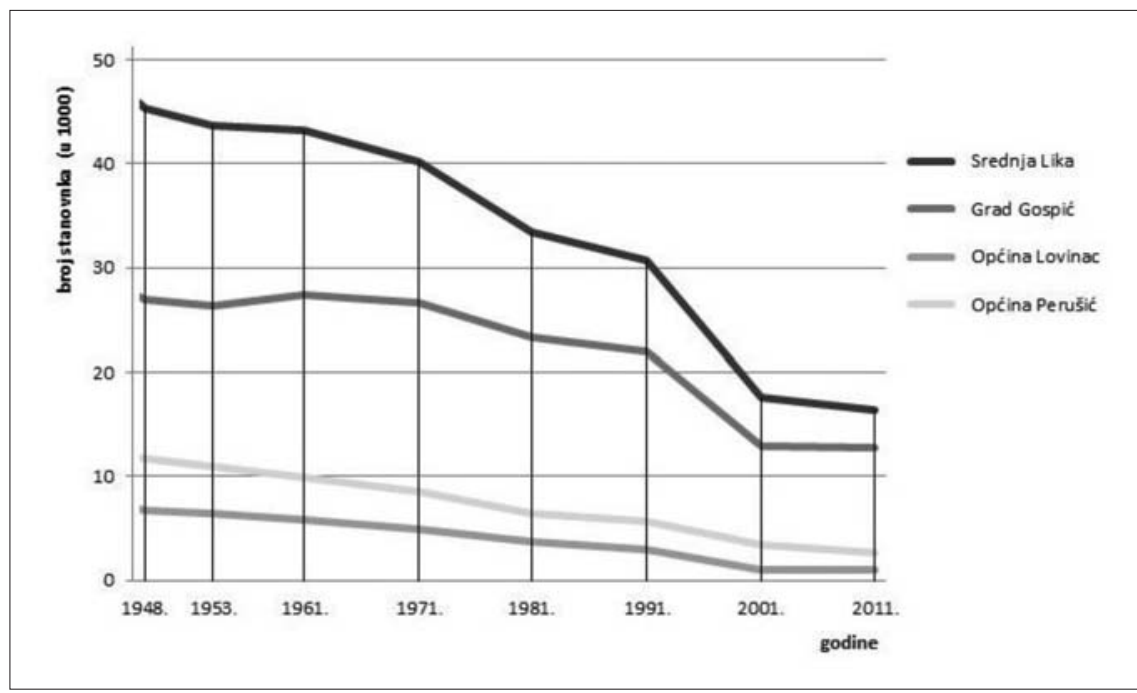

SI. 2. Kretanje ukupnog broja stanovnika Srednje Like i jedinica lokalne samouprave (1948.-2011.)

Izvor: Naselja i stanovništvo Republike Hrvatske 1857.-2001., DZS RH, Zagreb, www.dzs.hr. Pristup ostvaren 4. svibnja 2021 .; Popis stanovništva, kućanstava i stanova 2011 ., Stanovništvo prema starosti i spolu po naseljima, DZS RH, Zagreb, www.dzs.hr. Pristup ostvaren 4. svibnja 2021.

U novije vrijeme ipak se bilježe pozitivni trendovi kao što su povratak dijela stanovništva, koji se zbog Domovinskoga rata iselio u druga područja Republike Hrvatske i u inozemstvo (povratnici prognanika i izbjeglica). Također je značajno useljavanje stanovništva iz drugih, susjednih zemalja, ponajviše iz Bosne i Hercegovine. Međutim, na području Srednje Like u cjelini, kao i u svim jedinicama lokalne samouprave te u velikoj većini naselja, i u posljednjem popisu stanovništva (2001.-2011.) zabilježeno je smanjenje ukupnog broja stanovnika. Opažanjima na terenu utvrđeno je za navedeno područje kako je došlo do zapuštanja, tj. ekstenzifikacije korištenja zemljišta koja se u krajoliku manifestira kroz vegetacijsku sukcesiju. S druge strane, samo za naselja Gospić i Lički Osik može se konstatirati da ukupan broj stanovnika raste gotovo kontinuirano od druge polovine 20. stoljeća (1948. 2011). Time se sukladno procesima deruralizacije i urbanizacije u grad Gospić doseljava stanovništvo iz cijele Like. Posljedično, grad se prostorno širi, ${ }^{16}$ naročito prema naselju Lički Osik te rezultira gotovo kontinuirano izgrađenim područjem (Gospić - Lički Osik). Opažanjima na terenu utvrđeno je za to područje da je došlo do intenzifikacije korištenja zemljišta koja se u krajoliku manifestira kroz izgradnju te održavanje poljoprivrednih površina.

16 Načelno je tu riječ o procesu suburbanizacije, međutim treba uzeti u obzir kako je riječ o naseljima manjeg broja stanovnika. 


\section{Promjene u sastavu stanovništva prema dobi}

Usporedbom podataka dobnog sastava stanovništva za popisne godine 1971. i 2011., vidljivo je kako se u promatranom razdoblju na području Srednje Like odvija proces starenja stanovništva (tab. 1).

Tab. 1. Stanovništvo Srednje Like prema velikim dobnim skupinama i indeksu starosti za 1971. i 2001. Izvor: Popis stanovništva i stanova 1971., Stanovništvo, rezultati po naseljima i opštinama, Savezni zavod za statistiku, Beograd, 1972; Popis stanovništva, kućanstava i stanova 2011 ., Stanovništvo prema starosti i spolu po naseljima, DZS RH, Zagreb, www.dzs.hr. Pristup ostvaren 4. svibnja 2021.

\begin{tabular}{|c|c|c|c|c|c|c|c|}
\hline \multicolumn{8}{|c|}{ 1971.* } \\
\hline GRAD/OPĆINA & \multicolumn{2}{|c|}{$0-19$} & \multicolumn{2}{|c|}{ 20-59 } & \multicolumn{2}{|c|}{$\geq 60$} & Indeks \\
\hline Sjedište općine & Aps. & $\%$ & Aps. & $\%$ & Aps. & $\%$ & starosti * * $^{*}$ \\
\hline GRAD GOSPIĆ & 8475 & 31,8 & 13871 & 52,0 & 4175 & 15,6 & 49,3 \\
\hline Gospić & 2565 & 31,9 & 4644 & 57,7 & 813 & 10,1 & 31,7 \\
\hline OPĆINA LOVINAC & 1511 & 30,7 & 2332 & 47,3 & 1066 & 21,6 & 70,5 \\
\hline Lovinac & 276 & 31,8 & 434 & 49,9 & 156 & 18,0 & 56,5 \\
\hline OPĆINA PERUŠIĆ & 2979 & 34,6 & 3984 & 46,3 & 1606 & 18,7 & 53,9 \\
\hline Perušić & 446 & 33,2 & 694 & 51,7 & 196 & 14,6 & 43,9 \\
\hline $\begin{array}{l}\text { SREDNJA LIKA } \\
\text { UKUPNO }\end{array}$ & 12965 & 32,2 & 20187 & 50,2 & 6847 & 17,0 & 52,8 \\
\hline \multicolumn{8}{|c|}{2011.} \\
\hline GRAD/OPĆINA & \multicolumn{2}{|r|}{$0-19$} & \multicolumn{2}{|c|}{ 20-59 } & \multicolumn{2}{|c|}{$\geq 60$} & Indeks \\
\hline Sjedište općine & Aps. & $\%$ & Aps. & $\%$ & Aps. & $\%$ & starosti $^{* *}$ \\
\hline GRAD GOSPIĆ & 2747 & 21,6 & 6639 & 52,1 & 3359 & 26,4 & 122,3 \\
\hline Gospić & 1456 & 22,1 & 3631 & 55,2 & 1488 & 22,6 & 102,2 \\
\hline OPĆINA LOVINAC & 159 & 15,8 & 409 & 40,6 & 439 & 43,6 & 276,1 \\
\hline Lovinac & 38 & 14,8 & 111 & 43,2 & 108 & 42,0 & 284,2 \\
\hline OPĆINA PERUŠIĆ & 403 & 15,3 & 1161 & 44,0 & 1074 & 40,7 & 266,5 \\
\hline Perušić & 204 & 23,9 & 433 & 50,8 & 215 & 25,2 & 105,4 \\
\hline $\begin{array}{l}\text { SREDNJA LIKA } \\
\text { UKUPNO }\end{array}$ & 3309 & 20,2 & 8209 & 50,1 & 4872 & 29,7 & 147,2 \\
\hline
\end{tabular}

*Razlika do 100,0\% odnosi se na kategoriju "nepoznato"

* *Indeks starosti izračunat je prema odnosu stanovništva starog 60 i više godina i stanovništva 0-19 godina

Udio zrelog stanovništva (20-59 godina) ostao je približno jednak, no udio stanovništva starog 60 i više godina je povećan (sa 17,0\% 1971. na 29,7\% 2011.). Dakle, povećanje udjela starog stanovništva je na račun mladog stanovništva (do 20 godina starosti) čiji se udio smanjuje (sa 32,2\% 1971. na $20,2 \%$ 2011.). Udjeli mladog i starog stanovništva u objema promatranim 
popisnim godinama govore da Srednja Lika ima duboko ukorijenjene karakteristike starog stanovništva, ${ }^{17}$ koje je sve starije.

Prikazani obrat u odnosu starog i mladog stanovništva može se pratiti i na temelju pokazatelja indeksa starosti $\left(\mathrm{i}_{\mathrm{s}}\right) .18 \mathrm{U}$ tablici 1 može se vidjeti kako je na razini Srednje Like u cijelosti, zatim u sve tri jedinice lokalne samouprave kao i njihovim sjedištima, indeks starosti za 2011. većih, nepovoljnijih vrijednosti nego za 1971. Također, s obzirom na to da je za 2011. na svim promatranim razinama vrijednost indeksa starosti veća od 100,0 može se zaključiti kako je broj starog stanovništva veći od broja mladog stanovništva. 19

Na razini jedinice lokalne samouprave Grad Gospić očekivano ima povoljniju dobnu strukturu $\left(i_{\mathrm{s}}=122,3\right)$ nego općine Lovinac i Perušić u kojima je broj starog stanovništva više nego dvostruko veći od broja mladog stanovništva $\left(i_{s}>200\right)$. Od sjedišta jedinica lokalnih samouprava, očekivano, grad Gospić ima najpovoljniji odnos starih i mladih $\left(i_{s}=102,2\right)$, dok je najnepovoljniji u naselju Lovinac $\left(i_{s}=284,2\right)$. Prikazano starenje stanovništva Srednje Like potvrđuje i grafički prikaz dobno-spolne strukture stanovništva za popisne godine 1971. i 2011. (sl. 3).

U grafičkom prikazu za 1971. mogu se uočiti proširenja, što upućuje na brojnije generacije iz kompenzacijskih razdoblja nakon Prvoga i Drugoga svjetskog rata. Također, može se uočiti kako je baza za 1971. osjetno šira nego baza za 2011. To ukazuje na opadajuće stope rodnosti stanovništva, što je posljedica starenja stanovništva, te upućuje na trend daljnjeg smanjenja stope rodnosti u budućnosti, odnosno povećanja udjela starog stanovništva. Time dobno-spolna struktura poprima suženiji oblik baze, odnosno oblik urne.

Temeljem prikazanog može se zaključiti kako je, kao posljedica niskog, odnosno negativnog prirodnog priraštaja i emigracije stanovništva u najboljoj fertilnoj dobi, proces demografskog starenja na području Srednje Like duboko ukorijenjen. Po svemu sudeći, jačeg je intenziteta u rubnim područji-

\footnotetext{
17 Starim se smatra ono stanovništvo u kojem dobna skupina 60 i više godina čini više od 12\% ukupnog stanovništva (Ivo NEJAŠMIĆ, Demogeografija, stanovništvo u prostornim odnosima i procesima, Školska knjiga, Zagreb, 2005).

18 Indeks starosti $\left(\mathrm{i}_{\mathrm{s}}\right.$ ) pokazatelj je brojčanog odnosa starog i mladog stanovništva (I. Nejašmić, Demogeografija, stanovništvo u prostornim odnosima i procesima). U ovom radu izračunat je $s$ velikim dobnim skupinama: 60 i više godina starosti $(\geq 60)$ te do 20 godina starosti (0-19).

19 Stanovništvo u kojem je vrijednost indeksa starosti veća od 100,0 definirano je kao tip izrazito duboka starost (I. Nejašmić, Demogeografija, stanovništvo u prostornim odnosima i procesima).
} 


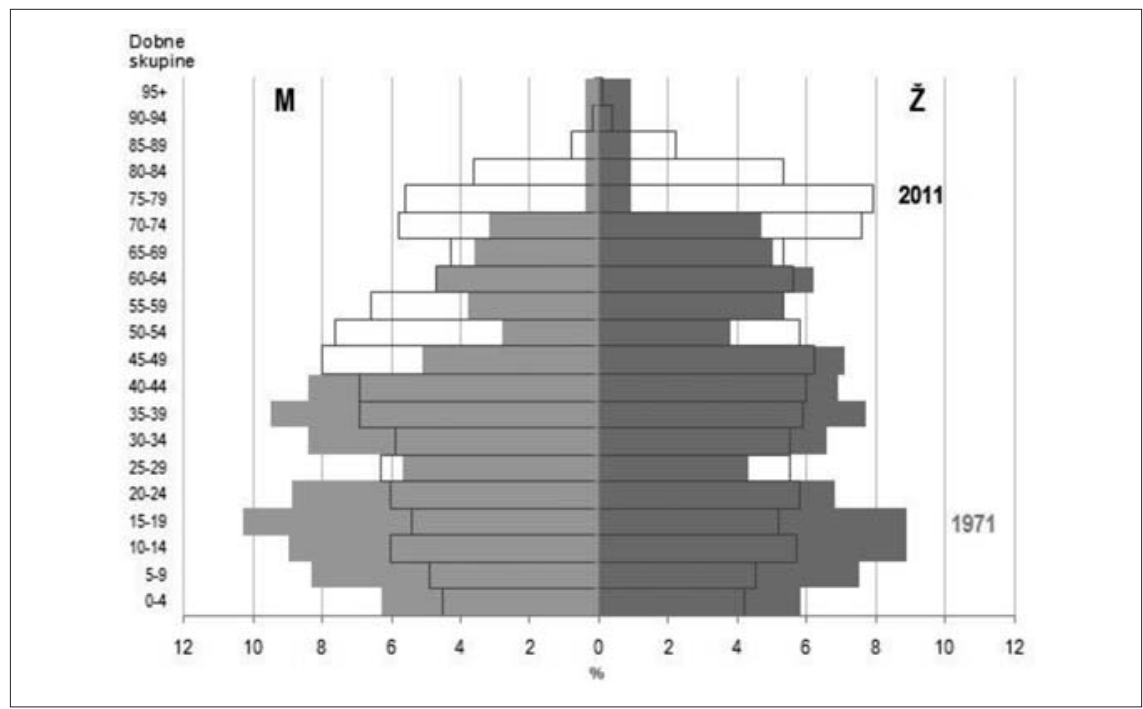

SI. 3. Sastav stanovništva Srednje Like prema dobi i spolu za 1971. i 2011.

Izvor: Popis stanovništva i stanova 1971., Stanovništvo, rezultati po naselijima i opštinama, Savezni zavod za statistiku, Beograd, 1972; Popis stanovništva, kućanstava i stanova 2011 ., Stanovništvo prema starosti i spolu po naseljima, DZS RH, Zagreb, www.dzs.hr. Pristup ostvaren 4. svibnja 2021.

ma, a slabijeg u središnjem dijelu, bliže gradu Gospiću. Navedeno je opažanjima na terenu utvrđeno i kroz jači intenzitet zapuštanja krajolika u rubnim područjima.

\section{Promjene u sastavu stanovništva prema sektoru djelatnosti}

Prethodno se moglo vidjeti kako su u razdoblju od druge polovine 20. stoljeća na razini Srednje Like neki od prisutnih procesa smanjenje ukupnog broja stanovnika, deruralizacija, urbanizacija. Uz navedene procese, na području Srednje Like može se utvrditi kako je u tom razdoblju opća stopa aktivnosti sve niža, što je uvelike uvjetovano starenjem stanovništva. Naime, dobni sastav stanovništva jedan je od demografskih pokazatelja koji u velikoj mjeri utječe na opću stopu aktivnosti, tj. na udio aktivnog u ukupnom stanovništvu.

Prema podatcima u tablici 2. vidljivo je kako je na razini Srednje Like u cijelosti, zatim u sve tri jedinice lokalne samouprave, kao i njihovim sjedištima, 2011. struktura zaposlenih prema djelatnostima značajno izmijenjena u odnosu na 1971. Time je došlo do prestrukturiranja stanovništva prema djelatnostima tercijarnog i kvartarnog sektora uz napuštanje tradicionalnih primarnih djelatnosti.

Analiza sastava stanovništva prema sektoru djelatnosti pokazala je prisutnost procesa deagrarizacije, tj. smanjenja udjela zaposlenih u primarnim 
djelatnostima, kako na razini Srednje Like ukupno, tako i na razini jedinica lokalne samouprave. Naime, došlo je do prestrukturiranja stanovništva prema djelatnostima tercijarnog i kvartarnog sektora.

Tab. 2. Struktura zaposlenog stanovništva Srednje Like prema sektoru djelatnosti za 1971. i 2011. Izvor: Popis stanovništva i stanova 1971., Stanovništvo, rezultati po naseljima i opštinama, Savezni zavod za statistiku, Beograd, 1972; Popis stanovništva, kućanstava i stanova 2011 ., Zaposleni prema područjima djelatnosti, DZS RH, Zagreb, www.dzs.hr. Pristup ostvaren 4. svibnja 2021.

\begin{tabular}{|c|c|c|c|c|c|c|c|c|}
\hline \multirow[b]{3}{*}{ GRAD/OPĆINA } & \multicolumn{4}{|c|}{ 1971.* } & \multicolumn{4}{|c|}{$2011 .^{*}$} \\
\hline & \multicolumn{4}{|c|}{ Sektor } & & \multicolumn{3}{|c|}{ Sektor } \\
\hline & Ukupno & I & $\|$ & III i IV & Ukupno & I & $\|$ & III i IV \\
\hline Sjedište općine & aktivno & $\%$ & $\%$ & $\%$ & aktivno & $\%$ & $\%$ & $\%$ \\
\hline GRAD GOSPIĆ & 12079 & 44,1 & 21,2 & 18,3 & 4684 & 7,5 & 16,7 & 65,0 \\
\hline Gospić & 3004 & 12,5 & 27,3 & 47,8 & 2641 & 6,0 & 14,0 & 70,5 \\
\hline OPĆINA LOVINAC & 2690 & 62,8 & 7,1 & 6,5 & 249 & 5,6 & 27,7 & 64,1 \\
\hline Lovinac & 487 & 52,6 & 4,5 & 10,1 & 74 & 5,4 & 18,9 & 55,4 \\
\hline OPĆINA PERUŠIĆ & 3956 & 59,3 & 13,8 & 7,3 & 701 & 12,1 & 23,5 & 49,8 \\
\hline Perušić & 544 & 29,4 & 28,9 & 24,4 & 266 & 8,3 & 14,7 & 63,2 \\
\hline
\end{tabular}

SREDNIA LIKA

\begin{tabular}{lllllllll} 
UKUPNO & 18725 & 50,0 & 17,6 & 14,2 & 5634 & 8,0 & 17,8 & 62,5 \\
\hline
\end{tabular}

*Razlika do 100,0\% odnosi se na aktivno stanovništvo koje je nezaposleno, zatim zaposleno u "nepoznatim aktivnostima" te na zaposlene u inozemstvu.

Opažanjem na terenu uočeno je kako su posjedi manje obrađeni u odnosu na raspoložive obradive površine; posjedi su mali i niska je tehnološka razina njihove obrade. Tako je područje Srednje Like, koje je potkraj 19. stoljeća bilo agrarno prenaseljeno, postalo nedovoljno poljoprivredno valorizirano. U krajoliku se to manifestira na oranicama, livadama i pašnjacima koji su pod (socijalnim) ugarom, odnosno doživljavaju proces zapuštanja. Time je smanjenjem ukupnog broja stanovnika i starenjem stanovništva, kao i deagrarizacijom, deruralizacijom i urbanizacijom, došlo do smanjenja poljoprivrednih aktivnosti što je dovelo do promjena u krajoliku. Smanjenjem bavljenja poljodjelstvom povećavane su neobrađene površine i zemljišta pod socijalnim ugarom. Također, smanjenjem bavljenja stočarstvom zapuštane su livade i pašnjaci, odnosno proširene travnate površine. To smanjenje površina koje su prije korištene za poljoprivredu, odnosno njihovo pretvaranje u travnate površine, može se nazvati zapuštanjem, tj. ekstenzifikacijom korištenja zemljišta koja se u krajoliku manifestira kroz vegetacijsku sukcesiju. 


\section{Zaključak}

U radu je promatrana promjena sastava stanovništva Srednje Like prema dobi i sektoru djelatnosti u razdoblju 1971.—2011. korištenjem prostorne i demogeografske analize. S obzirom na to da su navedena obilježja izravno povezana s kretanjem ukupnog broja stanovnika, provedena je analiza demografske dinamike Srednje Like svih općih popisa stanovništva u razdoblju od sredine 20. stoljeća (1948.—2011.) kada je započeo složeniji gospodarski razvoj te se usporedno pojavili procesi deagrarizacije, a zatim i deruralizacije. Pri tome su rezultatima istraživanja na gotovo cijelom području Srednje Like utvrđena vrlo nepovoljna kretanja promatranih popisnih pokazatelja. Opažanjima na terenu utvrđeno je kako se na gotovo cijelom području istraživanja odvija vegetacijska sukcesija, odnosno ekstenzifikacija korištenja zemljišta, a koja je većeg intenziteta bliže rubnim dijelovima Srednje Like. Međutim, povoljnija kretanja popisnih pokazatelja utvrđena su bliže gradu Gospiću, a u prostoru su vidljiva kroz izgradnju i održavanje poljoprivrednih površina, odnosno intenzifikaciju korištenja zemljišta.

Trenutačno zabilježene okolnosti nagoviještaju da se u narednim popisima stanovništva na analiziranom području može očekivati daljnji nastavak izrazito nepovoljnih demografskih i ekonomskih procesa. Stoga su učinkovita rješenja revitalizacije ovog područja prijeko potrebna.

Marta Hamzić

Modern developments in the population composition of Central Lika according to age and economic sector of activity - application of spatial and demo-geographic analysis

The main goal of this paper is to discuss the modern developments in the population composition of Central Lika according to the population's age and economic sector of activity. For this purpose, a spatial and a demo-geographic analysis were conducted by using census data from the years 1971 and 2011, both on the spatial level of local government units (and their seats), as well as Central Lika as a whole. Field observations helped understand the influence of established processes on the space, or rather the landscape of Central Lika. Additionally, in order to gain better insight, an analysis of the total population number trend for Central Lika was conducted, covering the time frame from the second half of the 20th century until now. By taking a closer look at the age of the population, the results of the research have shown that, in the covered time frame, a significant population ageing trend can be noted on all observed levels. This has led to the population pyramid taking the shape of an urn. For both studied years, the highest rate of population ageing has been noted in the Lovinac municipality, and the lowest in the Town of Gospić.

Furthermore, in the observed time frame, the general rate of activity in the 
Central Lika area is lower due to the ageing of the population. Moreover, there has been an economic sector restructuring in the population, with a stark shift toward the tertiary and quaternary sector, and the population abandoning traditional activities of the primary sector. Considering the current circumstances, in the upcoming population census, a continuation of severely adverse demographic and economic processes is expected in the analysed area.

Key words: population age composition, population activity sector composition, spatial analysis, demo-geographic analysis, landscape, Central Lika 